УДК 004.056

I. В. Миронець, к.т.н., доцент,

доцент кафедри інформаџійної безпеки та комп'ютерної інженерії,

e-mail: irenmir30@gmail.com

В. В. Орловський, магістрант

e-mail: bitali1994@gmail.com

Черкаський державний технологічний університет

б-р Шевченка, 460, м. Черкаси, 18006, Україна

\title{
ПРОГРАМУВАННЯ ЗАСОБІВ ОБРОБКИ ІНФОРМАЦІЇ У ХМАРНИХ СХОВИЩАХ НА ОСНОВІ ОПЕРАЦІЙНОÏ СИСТЕМИ ANDROID
}

Стаття присвячена створенню програмного продукту для статистичного аналізу та дослідженню ефективності обробки великих об'ємів даних на прикладі використання виділеного і хмарного серверів, який призначений для оцінювання використання хмарних технологій та виділених серверів; аналізується їх співіснування, виділено переваги та недоліки, приділено увагу опису відмінностей з роботою над великими об'ємами даних.

Ключові слова: інформаційні технологї̈, мобільний додаток, операційна система Android, хмарні сховища, захист даних.

Вступ. Найчастіше навіть чітко прописана специфікація протоколу взаємодії сервер/клієнт не може забезпечити коректну інтеграцію. Тому перед розробником виникає проста, очевидна проблема: протоколи клієнта і сервера не збігаються. 3 точки зору розробки клієнта це призводить до того, що мобільний додаток отримує некоректні дані або не отримує їх зовсім. При плануванні розробки проекту недооцінюється необхідний обсяг ресурсів і час створення сервера. Ще одна проблема - обмеженість доступних розробнику ресурсів. Найчастіше розробляти сервер доводиться за допомогою тих інструментів і технологій, якими володіють члени команди. Процес виходить тривалим, сам додаток - досить складним і дорогим 3 точки зору супроводу, а тривала розробка додатка, навіть у простих проектах, веде до збільшення витрат та інших ризиків.

Кожний день людина користується електронними пристроями; завдяки їм спілкується 3 друзями, заводить нових знайомих, замовляє необхідні товари. Таким чином, виникає необхідність у створенні нових програм і додатків для роботи з цими пристроями - як розважального характеру, так і для роботи, освіти та ін.

Отже, мобільна розробка - це галузь, яка стрімко розвивається, охоплює всі сфери життя людини і надає широкий вибір послуг, розрахованих на потреби різного типу. Мобі- льні додатки допомагають користувачам економити власний час, виконують багато важливих функцій та роблять життя простішим. Дуже мало програм працюють без певного підключення до Інтернету, тобто вони взаємодіють 3 бекендом, веб-сервісами або АРІ, які можуть бути надані різноманітними сервісами.

Актуальність. Хмарні технології з кожним роком все ширше використовуються для задоволення різних потреб населення. I, якщо раніше хмарні технології використовувалися вузьким колом ІТ-спеціалістів, то сьогодні ця технологія $є$ доступною для кожного користувача. Використання безкоштовного поштового сервісу gmail компанії Google, Hotmail компаніï Microsoft, використання віртуальних дискових просторів, додатків для спільної роботи віддалених користувачів та інших сервісів стали звичними для людства. Широке використання хмарних технологій привело до появи специфічних для кіберпростору технологій загроз безпеці інформації. Тому досить актуальною $є$ розробка нових інформаційних технологій захисту інформації в кіберпросторі та безпеки хмарних обчислень [1-3].

У сфері програмування мобільного бекенду $є$ ряд вагомих розробок, серед яких можна виділити праці таких авторів: Макконнелла С., Ханта Е., Томаса Д., Мостової Н. О., Нечаюк Л. І., Новикова О. В., П'ятницького Г. Т., Сірого В. М. та інших [4-5, 9-10]. 
Проте особливості та переваги застосування Інтернет-технологій у діяльності цього сегмента залишаються не до кінця дослідженими через те, що ця тема перебуває на етапі стрімкого розвитку, і щороку ми отримуємо новітні технології для мобільної розробки. У час науково-технічного прогресу інновації в програмному бізнесі відіграють чи не головну роль у висококонкурентній боротьбі компаній за кожного клієнта $[7,11]$. Застосування новітніх технологій розробки мобільних додатків дає змогу програмістам підвищити ефективність програмних продуктів, знаходити нові резерви підвищення якості серверної частини, надання нових послуг.

Метою дослідження $\epsilon$ розроблення мобільного додатку для статистичного аналізу і дослідження ефективності обробки великих об'ємів даних на прикладі використання виділеного та хмарного серверів, який призначений для оцінювання використання хмарних технологій та виділених серверів, їх співіснування, виділення переваг та недоліків, опису відмінностей 3 роботою над великими об'ємами даних.

Виклад основного матеріалу. Хмарні сервіси дозволяють керувати централізованою базою даних, яка пропонує користувачам спільно використовувати вміст через хмару. Розробнику не потрібно розробляти власний сервер з використанням серверної технології, такої як Ruby або РНР. Коли сторонній постачальник послуг відповідає за базову ITінфраструктуру, розробник додатка більше не відповідає за придбання виділеного сервера або віртуальної машини. У той же час постачальник послуг може вирішити, як ефективно використовувати свою інфраструктуру, щоб обслуговувати запити від усіх своїх клієнтів. Як наслідок, постачальник послуг зазвичай не зобов'язаний виконувати постійне навантаження для конкретного клієнта. Замість цього програма обробляє запити від усіх клієнтів одночасно, витрачаючи лише обмежений час на обробку кожного запиту конкретного клієнта. Тому такі постачальники, як правило, платять своїм клієнтам на основі загальної кількості запитів, частоти запитів протягом певного періоду або загального часу, витраченого на обслуговування всіх запитів від клієнта.

Такий самий підхід добре працює для різних типів навантажень, оскільки сторонні постачальники послуг, як правило, мають еластичні, масштабовані послуги. Коли клієнти починають користуватись сторонньою службою, очікувана кількість запитів може бути низькою, а клієнти платять значно менше, ніж придбання, налаштовування та управління власною інфраструктурою на місці або в хмарі. Для більшої кількості запитів (або очікуваних, або несподіваних піків навантаження) клієнтам не потрібно додавати сервери, щоб масштабувати їх застосування. Натомість постачальник послуг піклується про збільшення навантаження. Безумовно, обробка більшої кількості запитів обійдеться дорожче, але в більшості випадків таке рішення ще ефективніше, ніж використання спеціалізованої IT-інфраструктури.

Створений програмний додаток використовується користувачами, в яких є мобільний пристрій або планшетний комп'ютер на операційній системі Android та доступ до мережі Інтернет. Призначення додатка - надання розробнику мобільних додатків можливості отримувати повну інформацію про серверні технології, а також дослідження їх характеристик та відмінностей на власному мобільному пристрої.

Функціональне призначення додатка це отримання детальної інформації про використання різних видів розробки серверної частини мобільних додатків. Користувач може виконати запрограмовані запити на один 3 вибраних серверів, які розроблені за різними технологіями (хмарні або виділені), отримати інформацію про реакцію на запити, переглянути статистичні дані у вигляді графіків, діаграм, вивести інформацію у лог-файл, переглядати всю необхідну інформацію завдяки зручному інтерфейсу.

Експлуатаційним призначенням додатка є: економія часу розробника мобільних додатків на вибір технології збереження та отримання даних 3 мережі Інтернет, дослідження принципів розробки мобільних додатків, тестування систем надання послуг по обробці даних; передбачений швидкий, зручний, простий та інтуїтивно зрозумілий інтерфейс користувача, який не потребує наявності спеціальних вмінь та навичок для використання додатка; підтримка переважної більшості мобільних пристроїв на операційній системі Android. 
Потреба в розробці цього програмного продукту полягає в тому, щоб надавати розробнику мобільних додатків правильний вибір технологій залежно від цілей використання даних.

Розроблена програма складена 3 двох частин - серверної, яку представляє "backend" за допомогою хмарних сервісів "firebase", "BackendLess", "Amazon AWS", "Microsoft Azure", "Kinvey", власного сервера, та клієнтської на базі мобільної операційної системи Android, яка знаходиться на мобільному пристрої користувача.

Серверна частина містить перелік користувачів 3 даними для входу, запрограмований об'єм даних з запитами на їх отримання та додавання даних з клієнта. Всі запити мають історію та необхідну інформацію для статистичного аналізу.

Клієнтська частина має дуже зручний інтерактивний інтерфейс для перегляду даних 3 сервера, завантаження даних, формування графіків і діаграм, відображення інформації 3 запитів та ін.

Додаток містить наступні функції для користувача:

- відображення великої кількості даних, отриманої від запиту на обраний сервер, з часом відгуку та об'ємом інформації;

- реєстрація та авторизація користувача через соціальні мережі: "Facebook", "Twitter", "Google" або електронну пошту;

- побудова графіка залежності об'єму даних від швидкості виконання запиту на різних серверних технологіях;

- пошук за допомогою запиту на сервер, який повинен повертати результат, додаток буде зберігати час, затрачений на відгук сервера, та об'єм переданої інформації;

- побудова діаграми залежності з зібраними статистичними даними всіх протестованих серверних технологій;

- відображення результатів аналізу протестованих серверних технологій, використаних у додатку з детальними висновками;

-збереження результатів у лог-файл та мобільну базу даних.

Користувач може зберігати отримані результати, додавати до них власні помітки, обмінюватись результатами 3 друзями через популярні соціальні мережі.

Особливістю створеного програмного продукту $є$ визначення та аналіз недоліків і переваг описаних технологій завдяки розробці власного аналізатора даних.

Висновки. В результаті проведеного дослідження спроектовано i розроблено Android-додаток для статистичного аналізу та дослідження ефективності обробки великих обсягів даних на прикладі використання виділеного та хмарного серверів. Програмний продукт складений $з$ двох частин - серверної та клієнтської. Серверна частина містить базу даних для обліку користувачів, переліку та надання тестових даних, логів тощо. Клієнтська частина має інтерактивний інтерфейс для перегляду списку серверів, виконання запитів на них, складання графіків, виконання аналізу результатів. Під час аналізу предметної області висвітлено основні проблеми використання Інтернет-технологій у сфері розробки програмного забезпечення. В результаті дослідження встановлено певні недоліки та переваги використання технологій хмарного та виділеного серверів. Для того, щоб додаток максимально відповідав поставленим вимогам, був зручним та багатофункціональним, перед його проектуванням та розробкою було розглянуто й проаналізовано існуючі методології та літературні джерела. Деякі з рішень, що були знайдені в цих методологіях, були використані під час проектування та розробки мобільного додатка. Проектування системи відбувалося 3 використанням об'єктно-орієнтованого підходу. Використання шаблонів проектування та окремі дизайнерські рішення розробника дозволили зробити систему гнучкою, що легко піддається модифікації, зрозумілою та надійною. Використання сучасних гнучких технологій розробки дозволить і надалі розширювати функціональність системи або вносити зміни до ії поточної функціональності. Інтерфейс програми було спроектовано з урахуванням потреб цільового користувача. Інтерфейс спроектований так, щоб будь-які дії займали у користувача мінімальну кількість часу, адже планується велика інтенсивність використання додатка. Велику увагу було приділено тестуванню та відлагодженню системи. Використання сучасних інструментів тестування, відлагодження і використання різних підходів та методів тестування, що найкраще підходять до тестування кожного окремого методу, дозволили зробити систему надійною та стійкою до можливих помилок. 
1. Облачные технологии / Монахов Д.Н., Монахов Н. В., Прончев Г.Б., Кузьменков Д. А. Москва: МАКС Пресс, 2013. $128 \mathrm{c}$.

2. Гребнев Е. Облачные сервисы. Москва: CNews, 2011. 282 c.

3. Клементьев И. П., Устинов В. А. Введение в облачные вычисления. УГУ, 2009. 233 с.

4. Клементьев И. П., Устинов В. А. Введение в облачные вычисления. 2-е изд. Москва: Интуит, 2016. $311 \mathrm{c.}$

5. Сейдаметова 3. С. Облачные технологии и образование. Симферополь: ДИАЙПИ, 2012. 204 c.

6. Шилдт Герберт. Јava. Полное руководство. Москва: Вильямс, 2012. 1104 с.

7. Майер Рето. Android 4. Программирование приложений для планшетных компьютеров и смартфонов. Москва: ЭКСМО, 2013. $816 \mathrm{c}$.
1. Monakhov, D. N., Monakhov, N. V., Pronchev, G. B., Kuzmenkov, D. A. (2013) Cloud Technologies. Moscow: MAX Press, 128 p. [in Russian].

2. Grebnev, E. (2011) Cloud services. Moscow: CNews, 282 p. [in Russian].

3. Klementyev, I. P., Ustinov, V. A. (2009) Introduction to cloud computing. UGU, 233 p. [in Russian].

4. Klementyev, I. P., Ustinov, V. A. (2016) Introduction to cloud computing. 2nd ed. Moscow: Intuit, 311 p. [in Russian].

5. Seydametova, Z. (2012) Cloud technologies and education. Ukraine, Simferopol: DIAIPI, 204 p. [in Russian].

6. Shildt, Herbert. (2012) Java. Complete guide. Moscow: Williams, 1104 p. [in Russian].

7. Mayer, Reto. (2013) Android 4. Programming of applications for tablet computers and smartphones. Moscow: EKSMO, 816 p. [in Russian].

I. V. Myronets, Ph.D., associate professor, associate professor of information security and computer engineering chair, e-mail: irenmir30@gmail.com

V. V. Orlovskyi, master e-mail: bitali1994@gmail.com

Cherkasy State Technological University

Shevchenko blvd, 460, Cherkasy, 18006, Ukraine

\section{INVESTIGATION OF THE FEATURES OF PROGRAMMING OF INFORMATION PROCESSING METHODS IN CLOUD STORAGES BASED ON THE ANDROID OPERATING SYSTEM}

As a result of undertaken study, Android-supplement for a statistical analysis and research of the efficiency of processing large amounts of data on the example of the use of distinguished and cloudy servers is projected and worked out. A software product is made of two parts - server and client ones. Server part contains the data base for users accounting, listing and granting of test data, ravines, etc. Client part has an interactive interface for the revision of servers list, implementation of requests to them, drafting of diagrams, implementation of analysis of results. During the analysis of subject domain the basic problems of the use of Internet-technologies in the sphere of software development are cleared up. As a result of research certain advantages and disadvantages of the use of technologies of cloudy and distinguished servers are set. In order for the application to maximally meet the laid down requirements, be comfortable and multifunction, before its planning and development the existing methodologies and literary sources have been considered and analyzed. Some of solutions that have been found in these methodologies are used during planning and development of mobile application. 
Planning of the system took place with the use of object-oriented approach. The use of planning models and separate designer decisions of developer have allowed to do the system flexible, that easily yields to modification, clear and reliable. The use of modern flexible technologies of development will allow in future to extend the system functionality or make alterations to its current functionality. A program interface is projected taking into account the necessities of a target user. An interface is designed so that any actions would occupy the least of time for a user, because a large intensity of application use is planned. Large attention is paid to testing and adjusting of the system. The use of modern instruments of testing and adjusting and the use of different approaches and methods of testing which match the best for testing of every separate method allow to do the system reliable and proof to possible errors.

Keywords: information technologies, mobile application, Android operating system, cloud storages, data protection. 